\title{
The Oriental White-eyes hosts plaintive Cuckoo and Rusty-breasted Cuckoo
}

\author{
WAHYU WIDODO`, EKO SULISTYADI \\ ${ }^{1}$ Research Center for Biology, Indonesian Institute of Sciences. Cibinong Science Center, Jl. Raya Jakarta - Bogor Km 46, Cibinong, Bogor 16911, West \\ Java, Indonesia. Tel.: +62-812-8072 2215, vemail: bultok44@gmail.com
}

Manuscript received: 28 March 2019. Revision accepted: 2 July 2019.

\begin{abstract}
Widodo W, Sulistyadi E. 2019. The Oriental White-eyes hosts plaintive Cuckoo and Rusty-breasted Cuckoo. Biodiversitas 20: 2093-2100. The research aims to indicate that there is a tendency that the Oriental White-eyes Zosterops palpebrosus is used as a host for Plaintive Cuckoo Cacomantis merulinus and Rusty-breasted Cuckoo Cacomantis sepulcralis. The researches were done in the year 2009, 2014, 2016 and 2018 in some conservation forest areas in Mount Pancar Recreation Nature Park and Mount Telaga Bodas Nat ure Reserve (West Java), Mount Wilis forest (East Java) and Mount Merapi National Park forest (Centre Java). The explorative method was used in this research. We found the fact that, at some occurrences, young Plaintive Cuckoo and Rusty-breasted Cuckoo have been hosted and fed up by a pair of Oriental White-eyes Zosterops palpebrosus. It is new information because this occurrence has never been reported before. That research, however, needs to be continued for further information. Among other things, the research is started with the presence of the Oriental White-eyes' nest and the strategy of Plaintive Cuckoo and Rusty-breasted Cuckoo to place its egg into the nest of Oriental White-eyes. This research implicates to remind the management authority to maintain the population of remaining songbirds either in conservation areas or in non-conservation areas, as well as their buffer zones.
\end{abstract}

Keywords: Host, Oriental White-eyes, Plaintive Cuckoo, Rusty-breasted Cuckoo

\section{INTRODUCTION}

There are 54 species of Cuculidae in Indonesia which are distributed in many locations from Java (20 species), Sumatra (26 species), Kalimantan (24 species), Bali (7 species), Nusa Tenggara (16 species), Moluccas (18 species), Celebes (17 species) and Papua (22 species) (Beehler and Zimmerman 1986; MacKinnon et al. 1998; Coates and Bishop 2000). The Plaintive Cuckoo Cacomantis merulinus and Rusty-breasted Cuckoo Cacomantis sepulcralis are inclusive species belonging to Cuculidae family. Plaintive Cuckoo is a common bird and found in resident settlement areas at forest edge, and Rustybreasted Cuckoo is found in the higher altitude of forest (MacKinnon 1990). "Kedasih Bird" is cuckoo's name given by Javanese people. In Java myth, "Kedasih" is recognized as bird sign of the occurrence of a disease (Tjakraningrat 1965). Voice of the cuckoo which is heard from a tree in page-yard of somebody's house is believed to be the sign of the worse illness of person in that house which can bring to death.

Plaintive cuckoo and Rusty-breasted Cuckoo are brood parasitism in birds (MacKinnon 1990). Brood Parasitism in birds is defined as the interaction in which a bird species (parasitic) places its eggs in the nest of host species with the intention of freeing itself from parental obligations. The parasitic species only has to find a nest to place the eggs and will not see its offspring again (Avian Report 2018). Hosts of Plaintive Cuckoo reported by Lowther (2015) are Little Spiderhunter Arachnothera longirostra (Nectariniidae), Bar-winged Prinia Prinia familiaris, Common Tailorbird Orthotomus sutorius, Zitting Cisticola
Cisticola juncidis (Sylviidae), and Crescent-chested Babbler Stachyris melanothorax (Timaliidae). Then, hosts of Rusty-breasted Cuckoo are Long-tailed Shrike Lanius schach (Laniidae), Hill Blue-flycatcher Cyornis banyumas (Muscicapidae) and Rufous-tailed Fantail Rhipidura phoenicura (Rhipiduridae).

In reality, among hosts cuckoos are songbirds. The songbirds are more popular by society. For a long time, it has been realized that the population of songbirds tend to descend due to several factors, among other things, the forest fragments in various places and the benefit of various birds in the song-bird contest (Iskandar and Iskandar 2015).

The aim of this research is to know the existence of new possible hosts for Plaintive Cuckoo and Rusty-breasted Cuckoo. Its result is expected to be able to provide information for the management of authority in the reconstruction of habitat and also in monitoring the continuity of songbirds and cuckoos population in various Java regions. We know that the cuckoos have the function and role in nature as a predator of pest.

\section{MATERIALS AND METHODS}

Research material is a community of parasite birds, its eggs, its nests, and its habitat. The researches were conducted in some Java region in July 2009, April 2014, May 2016 and May 2018. The explorative methods were used in these researches. Information from local society (farmers) or field assistant is also needed to found the Cuckoo's nests. Average time for each the explorations of 
the nest, egg and also occurrence of young cuckoos and their hosts in every research location was about 4 hours. Totally, each observation was 16 hours. Research appliance used binocular, GPS, Camera, Digimatic Caliper and notebook with the pens.

\section{Research sites and general habitat \\ Mount Pancar}

The Mount Pancar is the forest of Park of Recreation Nature, situated in the region of Karangtengah Countryside, sub-district of Babakan Madang, Bogor Regency, West Java Province. Their location is about 20 $\mathrm{km}$ east of Bogor Botanical Garden, Bogor. The research was done at 1 until 10 July 2009. The core forest of Mount Pancar remained in top with some plants, namely "kihaji" (Dysoxylum blumei), spike oak (Lithocarpus elegans), rattan (Calamus sp) and "jirak-jirakan" (Symplocus fasciculata and Symplocus javanica), huru hiris (Actinodaphne sphaerocarpa), "kibonteng" (Ficus virens), "kiara kebo" (Ficus stupenda), and "kiara pereng" (Ficus gibbosa).

The plant composition at the frontier of an area of Mount Pancar and their buffer zone are Pine (Pinus sp), immeasurable of fruit plants and the hardwoods. Those plants in those buffer zone, i.e. durian (Durio zibethinus), avocado (Persea americana), mango (Mangifera indica), rambutan (Nephelium lappaceum), picung or "football fruit" (Pangium edule), candlenut (Aleurites moluccana), petai (Parkia speciosa), dog fruit (Pitheceliobium jiringa), China berry (Melia azedarach), needle wood (Schiima wallichii), figs (Ficus stupenda), red sandalwood (Pterocarpus indica), muzizi (Maesopsis eminii), cloves ( Eugenia aromaticum) and coffee plants (Coffea arabica).

Altitude variation of Mount Pancar is about 469-869 m asl. Band of exploration of parasite birds conducted around of the Garenggong and Gegenteng area and the geographical is $6^{\circ} 35^{\prime} 43.3^{\prime \prime} \mathrm{S}$ and $106^{\circ} 54^{\prime} 56.52^{\prime \prime} \mathrm{E}$.

\section{Mount Telaga Bodas}

This research was done in the Perhutani forest area, where it borders the Nature Reserve and Nature Tourism Park of Mount Telaga Bodas, Garut Regency, West Java. The research was conducted on 25-29 April 2014. The research location was about $30 \mathrm{~km}$ east of Garut town. The location is inclusive of Sukamenak countryside, Wanajaya District, Garut Regency. The habitat in the natural forest of Mount of Telaga Bodas was composed by Suanggi (Vaccinium varingifolium), pasang (Quercus platycorpa) and saninten (Castanopsis argentea). Generally, bird habitat represents the land of Perhutani forest mostly have been opened. Farmer society rents the land for cultivating the commodity of plants, like potato, cabbage, chili, tomato, onion leaf and of a kind. Farmer also plants the Coffea crop with the shade trees of Needlewood (Schiima wallichii), Pine (Pinus merkusii), muzizi (Maesopsis eminii), "kayu putih" (Eucalyptus sp. ), teak (Tectona grandis), and suren toon (Toona sureni). The research's coordinate is $7^{\circ} 11^{\prime} 26.9^{\prime \prime}-7^{\circ} 11^{\prime} 32.8^{\prime \prime} \mathrm{S}$ and $108^{\circ} 3^{\prime} 21.4^{\prime \prime}$ $108^{\circ} 3^{\prime} 25.6^{\prime \prime} \mathrm{E}$, with their altitude ranged from 1.549 to $1.599 \mathrm{~m}$ asl.

\section{Mount Wilis}

The research was done in the Perhutani nature forest near Mount Wilis, Madiun Regency, East Java. The research was conducted on 9-15 May 2016. The position is about $30 \mathrm{~km}$ east of Madiun town. Most bird habitat consisted of the grove of farm food resources, like Balik Angin (Mallotus paniculatus), Macaranga rhizinoides, pigeon wood (Trema orientalis), Figs (Ficus sinuata and Ficus tricolor), great Malay bean (Engelhardtia spicata), tanbark oak (Lithocarpus elegans), white oak (Castanopsis acuminatissima), scaly ash (Psychotria fimbricalyx) and Chinquapins.

The border of natural forest land and the buffer zone in Mount Wilis was marked by the Pine (Pinus sp). Some other part of the land has been exploited by society to be planted with the coffee with the shade trees of cloves (Eugenia aromaticum), cinchona (Cinchona pubescens), white lead tree (Leucaena leucocephala), mahogany (Swietenia mahagony), suren toon (Toona sureni) and grey teak (Gmelina arborea). Some lands of Perhutani forest have become Coffee plantation area cultivated by residents of the Pulosari hamlet, Kare sub-district, Madiun District, East Java Province. Research's co-ordinate was at $7^{\circ} 46^{\prime}$ 46.2" South and $111^{\circ} 42^{\prime} 57.6^{\prime \prime}$ East, with the altitude ranged from 1.100 to $1.500 \mathrm{~m}$ asl.

\section{Mount Merapi}

The research of parasite birds in the area of Mount Merapi National Park forest was done at the date of 1-5 May 2018. That was around Hill Turgo Pines forest. The location is about $25 \mathrm{~km}$ north of Yogyakarta town. Administratively, Hill Turgo residents are in the region of Turgo hamlet, Purwobinangun countryside, Pakem subdistrict, Sleman Regency, DIY. The area of around Hill Turgo was predominated by the plant of hardwoods and fruits crop. Among other things are needle wood (Schima wallichii), cinnamon (Cinnamomum verum), Pine (Pinus merkusii), gnemon (Gnetum gnemon), cacao (Theobroma cacao), clove (Syzygium aromaticum), white albizia (Paraserianthes falcataria), dammar gum (Agathis dammara), mahogany (Swietenia mahagony), avocado (Persea americana), durian (Durio zibethinus), nangka (Artocarpus heterophyllus), rambutan (Nephelium lappaceum), klengkeng (Dimocarpus longan), coconut (Cocos nucifera), coffee (Coffea arabica), sengon besia, guava (Psidium guajava), chinaberry (Melia azedarach), coastal cottonwood (Hibiscus tiliaceus), and bamboos (Bambusa sp.).

Under vegetation was the bushes like red calliandra (Calliandra calothyrsus) and white calliandra (Calliandra tetragona), Lantana camara, and Siam weed or "kirinyuh" (Chromolaena odorata). There was also grasses like King grass (Pennisetum purpureum), Setaria grass (Setaria sphacelata), Para grass (Brachiaria mutica) and tepustepusan (Achasma sp.). The original orchids of Turgo Hill were also found, for example, Dendrobium mutabile, Dendrobium sagitatum, and Vanda tricolor, with its host on Schima wallichii tree. The exploration of parasite birds in Hill Turgo was conducted in the geographical mark on 
$7^{\circ} 35^{\prime} 8^{\prime \prime} \mathrm{S}$ and $110^{\circ} 24^{\prime} 53.3^{\prime \prime} \mathrm{E}$, with an altitude of about $1027 \mathrm{~m}$ asl.

\section{Descriptive analyze}

Data of species of young Cuckoos and its host were analyzed descriptively by investigating its morphological characteristics, such as the condition of nests and its eggs found in the field. The characteristic of birds was confirmed with the specimen collection the birds and eggs in the Museum of Zoology, Cibinong, Bogor, Indonesia. Voice of young Cuckoos were recorded directly and compare them to birds' voice record in online reference (Xeno-canto.org).

\section{RESULTS AND DISCUSSION}

Indonesia has more than 50 bird species of Cuculidae family. Most of Cuculidae is distributed in Sumatra and Borneo i.e. 25 species, respectively. Then, it is followed by 21 species in Java and Papua, 17 species in Moluccas (Maluku), 15 species in Celebes (Sulawesi), 12 species in Bali and 11 species in the region of Nusa Tenggara. The widest distribution of Cuculidae is Oriental Cuckoo Cuculus saturatus and Asian Koel Eudynamys scolopacea spreading in 8 regions, namely Java, Bali, Nusa Tenggara, Sumatra, Borneo, Celebes, Moluccas, and Papua. Then, it is followed by Rusty-breasted Cuckoo Cacomantis sepulcralis (7 regions) and Drongo-Cuckoo Surniculus lugubris (6 regions).

Most Cuculidae was known as "avian bird brood parasitism". They breed but they need other bird species as host to make the nest, to lay eggs, to brood and to incubate them. At the time of which almost at the same time as the host bird lays its egg, this parasite bird partake to lay eggs in the nest of the host, and let the host to brood and incubate the eggs. Until, the young Cuculidae fully grew, in the host's nest, Cuculidae provides no food for its youngsters at all or involves in the process of mothering. The process of the birds' parasite to get the host uses mimetic strategy (Yang et al 2012) and instinct (Anon. 2019). Sometimes, in such a way that that prolific parasite bird egg is "indistinguishable" with the egg of host from the eyes of human (Krüger 2011).

In Indonesia, not all Cuculidae family is categorized as bird brood parasites. Birds of Phaenicophaeus spp and Centropus spp will build the nest, breed, hatch the eggs and raise its youngster by itself without a host to support it (MacKinnon 1990). There were some detail reports about parasite birds from Cuculidae and its host in other nation (Lowther 2015). But, in Indonesia, such study has not been reported before. The information about the parasite bird is still limited scientifically. Still, researches of brood parasitism especially in Java have been blazed the way in the year 1949s (Hoogerwerf 1949a and 1949b). The result of that research in prolific parasite birds from Cuculidae with its hosts in Indonesia, especially in Java, is shown in Tables 1.
Table 1 indicates that host for parasite birds is mostly resident species in Indonesia. Among other things, Rustybreasted Cuckoo Cacomantis sepulcralis is noted to have the host of 30 species and host Plaintive Cuckoo Cacomantis merulinus is noted to have the host of 18 species. Plaintive Cuckoo Cacomantis merulinus and Rusty-breasted Cuckoo Cacomantis sepulcralis are parasite birds which are commonly found in some region in Java (Widodo 2013, Widodo 2015, Widodo 2016). Plaintive Cuckoo is a more commonly found at the hilly area $( \pm 800$ $\mathrm{m}$ asl), while rusty-breasted cuckoo is found at higher level mountain forest $( \pm 1.000 \mathrm{~m}$ asl). Still, plaintive cuckoo and rusty-breasted cuckoo take possession of the habitat which is similar to the area of production forest managed by the state forestry enterprise (Perhutani). For the second option, the species of cuckoo tends to take possession of the Coffee plantation habitat with the shade of various plant type, like flower crop, mahogany, gmelina and of a kind. Their topography relatively was rather open. That makes it possible for many kinds of nest and food sources to be observed and found easier Tejeda-Cruz and Sutherland (2004) and (Buechley 2015) reported that coffee plantations with shade trees are best for birds and may provide suitable habitat for several bird species.

The research of parasite birds of Cuculidae by its host in Java, especially the plaintive cuckoo and rusty-breasted cuckoo, has been done carefully. At July 2009, the first time we found a young Cuckoo is being fed by a pair of the host, in an area of Mount Pancar forest, Bogor, West Java. There are three land types in Mount Pancar forest to be searched and to be studied. Those consist of natural forest, fruit plants, and hardwoods. On 10 July 2009, at exactly about 07.00 am, we found a pair of the adult Oriental White-eyes Zosterops palpebrosus flying over and bringing food which seems like a small caterpillar. Then, those White-eyes fed up its young bird with the caterpillar. This young bird stood in the middle of small clove plant (Eugenia aromatica) and flew about $1 \mathrm{~m}$ high above land. The distance was about $5 \mathrm{~m}$ from our observation place. The young bird was caught by our guide. Then, that young bird was photographed by us and being described carefully. The young bird was weak when we documented it. Before releasing, we noted that feather of it is red-brown, barred with blackish spot on the upper parts. The inner beak is very yellow, while the bill and legs are yellowish. There is no line on their eyes. Then, feathers on the tail still have not yet grown completely (Figure 1). The vegetation of that site consists of some wood plants, namely musizi (Maesopsis eminii), tulip cedar (Melia azedarach), the football-fruit (Pangium edule), wild mango (Mangifera caesia), coffee (Coffea arabica) and clove trees (Eugenia aromatica), pines (Pinus merkusii) and also cassava, bananas and grasses. The young bird could only fly low around of our site's observation and a pair of Oriental White-eyes (Zosterops palpebrosus) was not so far, about 5 $\mathrm{m}$ from us. Those white-eyes foraged for any caterpillar or small insects which lived on the leaves of Pangium edule. This position was $6^{0} 35.433^{\prime}$ South, $106^{\circ} 54.942^{\prime}$ East, and altitude was $620 \mathrm{~m}$. 
Table 1. Brood parasites of Cuculidae in the recently*)

\begin{tabular}{|c|c|}
\hline Brood parasites species & Hosts \\
\hline $\begin{array}{l}\text { Chestnut-winged Cuckoo } \\
\text { (Clamator coromandus) }\end{array}$ & $\begin{array}{l}\text { Lanius schach, Garrulax spp., Zoothera citrina, Myiophonus caeruleus, Copsychus saularis, Pomathorinus } \\
\text { sp. }\end{array}$ \\
\hline $\begin{array}{l}\text { Large Hawk-Cuckoo } \\
\text { (Cuculus sparvarioides) }\end{array}$ & $\begin{array}{l}\text { Lanius schach nigriceps, Pycnonotus cafer, Stachyris nigriceps, Garrulax canorus, Brachypteryx } \\
\text { leucophrys. }\end{array}$ \\
\hline $\begin{array}{l}\text { Mustached Hawk- } \\
\text { Cuckoo (Cuculus vagans) }\end{array}$ & Tersiphone paradisi, Malacocincla abbotti. \\
\hline $\begin{array}{l}\text { Malay Hawk-Cuckoo } \\
\text { (Cuculus fugax)** }\end{array}$ & $\begin{array}{l}\text { Cymbirhynchus macrorhynchus, Culicicapa ceylonensis, Stachyris nigricollis, Cyanoptila cyanomelana, } \\
\text { Erythacus cyane, Copsychus malabaricus. }\end{array}$ \\
\hline $\begin{array}{l}\text { Indian Cuckoo } \\
\text { (Cuculus micropterus) }\end{array}$ & $\begin{array}{l}\text { Eurylaimus ochromalus, Aegithina tiphia, Lanius cristatus, Dicrurus macrocercus, Dicrurus leucophaeus, } \\
\text { Dicrurus paradisea, Tersiphone paradisi, Prinia flaviventris, Arachnothera affinis, Dendronanthus indicus. }\end{array}$ \\
\hline $\begin{array}{l}\text { Himalayan Cuckoo } \\
\text { (Cuculus saturatus)* }\end{array}$ & $\begin{array}{l}\text { Cettia fortipes, Spizixos semitorques, Phylloscopus occipitalis, Phylloscopus reguloides, Enicurus } \\
\text { schistaceus, Emberiza elegans. }\end{array}$ \\
\hline $\begin{array}{l}\text { Common Cuckoo } \\
(\text { Cuculus canorus)* }\end{array}$ & $\begin{array}{l}\text { Upupa epops, Lanius schach, Rhipidura aureola, Eremophila alpestris, Pycnonotus leucogenys, } \\
\text { Acrocephalus stentoreus, Dicrurus leucophaeus, Tersiphone paradisi, Hypothymis azurea, Culicicapa } \\
\text { ceylonensis, Parus major, Pycnonotus cafer, Pnoepyga pusilla, Megalurus palustris, Cisticola juncidis, } \\
\text { Cisticola exillis, Prinia flaviventris, Orthotomus sutorius, Stachyris rufifrons, Timalia pileata, Acippe } \\
\text { poioicephala, Zosterops palpebrosus, Chloropsis aurifrons, Sitta frontalis, Copsychus malabaricus, } \\
\text { Zoothera citrina, Passer montanus, Eumyias thalassina. }\end{array}$ \\
\hline
\end{tabular}

Banded Bay Cuckoo (Cacomantis sonneratii)

Aegithina tiphia, Aegithina viridissima, Rhipidura javanica, Pycnonotus jocosus

Plaintive Cuckoo

(Cacomantis merulinus)

Aegithina tiphia, Aegithina viridissima, Aethopyga maxima, Aethopyga mystacallis, Cisticola juncidis, Prinia atrogularis, Prinia hodgsonii, Prinia familiaris, Prinia flaviventris, Prinia inornata, Prinia subflava, Orthotomus sutorius, Orthotomus atrogularis, Orthotomus sepium, Orthotomus ruficeps, Aethopyga siparaja, Arachnothera affinis, Arachnothera longirostra.

Rusty-breasted Cuckoo (Cacomantis sepulcralis)

Horsfield's Bronze Cuckoo (Chrysococcyx basalis)*

Little Bronze Cuckoo (Chrysococcyx minutilus)

Violet Cuckoo

(Chrysococcyx xanthorhynchus)

Square-tailed Drongo Cuckoo (Surniculus lugubris)

Asian Koel (Eudynamys scolopacea)
Lichmera indistincta, Philemon corniculatus, Malurus cyaneus, Malurus coronatus, Lichenostomus virescens, Sericornis frontalis, Gerygone fusca, Pachycephala pectoralis, Lanius schach, Culicicapa ceylonensis, Microeca flavigaster, Rhipidura euryura, Rhipidura phoenicura, Rhipidura javanica, Rhipidura leucophrys, Monarcha trivirgatus, Muscicapa vulcani, Myiagra ruficollis, Pycnonotus aurigaster, Orthotomus cucullatus, Megalurus palustris, Zosterops lateralis, Zosterops buruensis, Cyornis banyumas, Ficedula hyperythra, Enicurus velatus, Enicurus leschenaulti, Saxicola caprata, Leptocoma sericea, Cynniris jugularis.

Malurus spp., Myzomela sanguinolenta, Lichmera indistincta, Lichenostomus spp., Acanthornis spp., Sericornis humilis, Calamanthus spp., Acanthiza spp., Gerygone fusca, Gerygone olivacea, Daphoenositta chrysoptera, Pachycephala rufiventris, Rhipidura leucophrys, Cisticola exillis, Zosterops lateralis, Acrocephalus stentoreus, Megalurus palustris,Dicaeum hirundinaceum, Cynniris jugularis, Passer domesticus

Malurus amabilis, Taeniopygi guttata, Ramsayornis fasciatus, Conopophila rufugularis, Gerygone spp.

Orthotomus sutorius, Prinia flaviventris, Cisticola juncidis, Malacocincla abbotti, Napothera epilepidota, Dicaeum agile, Anthreptes malacensis, Aethopyga siparaja, Cynniris jugularis, Arachnothera longirostra.

Lanius sp., Pycnonotus cafer, Pycnonotus aurigaster, Enicurus sp., Orthotomus sutorius, Malacocincla sepiarium, Pellorneum albiventer, Malacopteron affine, Stachyris rufifrons, Stachyris melanothorax, Macronous gularis, Macaronous flavicollis, Alcippe poioicephala.

Philemon buceroides, Lanius schach, Dicrurus macrocercus, Oriolus chinensis, Corvus splendens, Corvus enca, Corvus macrorhynchos, Acridotheres tristis, Acridotheres grandis, Gracula religiosa.

Sources: Hoogerwerf (1949a, 1949b, 1949c); MacKinnon (1990); Lowther (2015). *=Migrant, **=Visitor

Then, we have done a study in the area of forest of Mount Telaga Bodas, Garut at plain which was relatively high at about $1400-1600 \mathrm{~m}$. At the periphery of nature reserve forest, there is an area of horticulture plantation, like as tomato, chilies, onion leaf, potatoes, and coffee trees. The coffee crops were shaded by the tree of "Puspa" 
Schima wallichii. At the research on the date of 26 April 2014, we found a nest of Long-tailed Shrike Lanius schach placed at Schima wallichii tree as high as about $4 \mathrm{~m}$. The position of the nest was about 1489 to $1581 \mathrm{~m}$ and at $7^{0} 10^{\prime}$ $46.2^{\prime \prime}$ to $7^{0} 11^{\prime} 23.3^{\prime \prime}$ South and $108^{\circ} 3^{\prime} 21.9^{\prime \prime}$ to $108^{\circ} 4^{\prime} 9.4^{\prime \prime}$ East. At that time, we found only 3 eggs of Long-tailed Shrike and there was no egg of Cuckoo. The Long-tailed Shrike eggs' colors are white with green spots.

Third research was conducted in the forest area of Mount Wilis, Madiun (East Java). In that area, the research was done on 9 May to 17 May 2016, in natural forest and also in the area of coffee plantation managed by the private sector and pine (Pinus sp) owned by the state forestry enterprise (Perhutani) Branch of East Java. After tracing in the forest area, we found some nests, i.e. the nest of Whitebibbed Babbler Stachyris thoracica, Crescent-chested Babbler Stachyris melanothorax, White-crowned Forktail Enicurus leschenaulti, and Long-tailed Shrike Lanius schach. On 12 May 2016, we found a nest of Long-tailed Shrike, but in the nest, there was a young Cuckoo. Coordinate position was $7^{0} 46^{\prime} 46.2^{\prime \prime} \mathrm{S}$ and $111^{\circ} 42^{\prime} 57.6^{\prime \prime} \mathrm{E}$, the altitude was $1252 \mathrm{~m}$. However, the nest was dwelt by a young Cuckoo which cannot fly yet. Not so far from nest, there was the host, Long-Tailed Shrike, which likely took care of the young Cuckoo. That nest was located at the tree of mahogany Swietenia mahagoni as high as about $5 \mathrm{~m}$. We took the nest and young Cuckoo for a while to get pictures of them. Young Cuckoo has the yellow beak with black spot at the middle of the bill, brown eyes with white ringeyes, blackish legs. The plume on back-part and under-part of the body were auburn and turned to be clear white at the end (Figure 2).

We have done the last research in the forests area of Mount Merapi National Park forest, at Yogyakarta. That was on 1 May to 7 May 2018. It was about a week before Mount Merapi National Park eruption on 11 May 2018. The location was in the area of forest of Turgo Hill, Mount Merapi National Park, Yogyakarta. That location's coordinate was $7^{0} 35^{\prime} 8^{\prime \prime} \mathrm{S}$ and $110^{\circ} 24^{\prime} 53.3^{\prime \prime} \mathrm{E}$ and altitude $1027 \mathrm{~m}$. It was less than $5 \mathrm{~km}$ from the center of the cauldron of fire of Mount Merapi. That region is inclusive of the regional frontier of countryside Banjar Harjo, Turgo, Purwobinangun, district of Pakem and Kumpul Rejo countryside, Girikerto of district Turi, Sleman. About 20 minutes more, we concerned to observe a pair of the Oriental White-eyes Zosterops palpebrosus feeding up young cuckoo with, likely, caterpillar or insect. The characteristics of young cuckoo were as follows: irises are brown; the bill is black; and legs are yellowish or grayish. For feathers, the one on the head is grey; the chest is brown to blackish with certain pattern; and the tail is white to brown (Figure 3 ). We saw a young cuckoo flew quickly to follow their host Zosterops palpebrosus at the time of observation. Their habitats were on avocado tree Persea americana, needle wood tree Schima wallichii, bamboos, silk tree Albizia sp and true cinnamon tree Cinnamomum zeylanicum. The average height of trees was more than 10 $\mathrm{m}$, its condition was dense. Since the wind was very fast, it was relatively difficult to do the observation with the binoculars. The birds also often tried to hide behind the leaves.

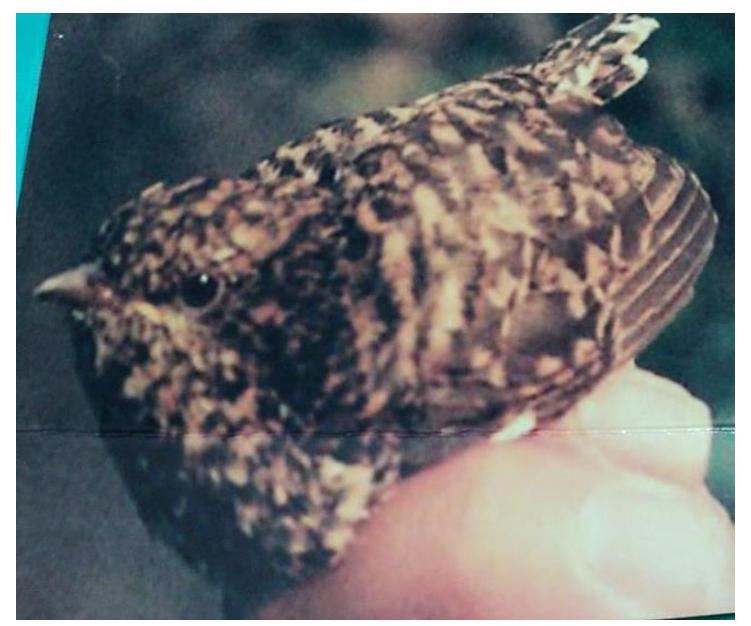

Figure 1. A young cuckoo at Mount Pancar Tourism Park forest, West Java, Indonesia (just fledging and flight low)

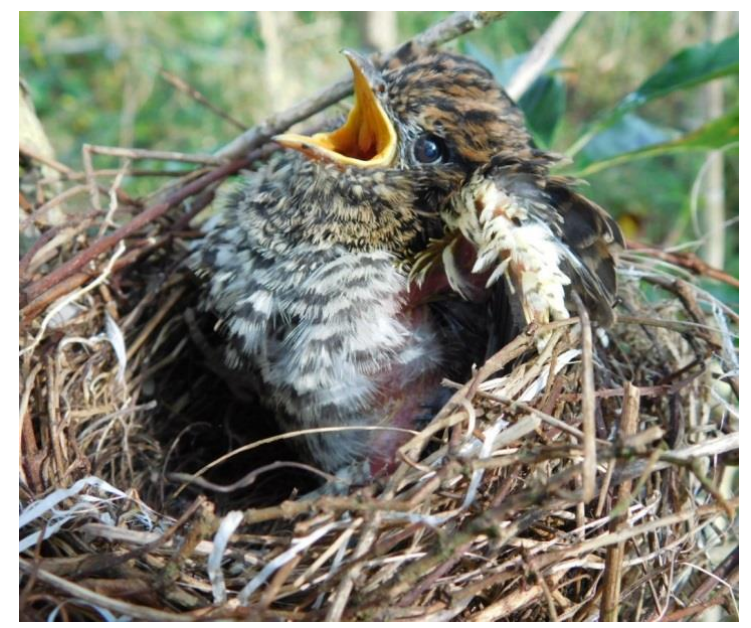

Figure 2. A young cuckoo at Mount Wilis forest, East Java, Indonesia (still in the nest)

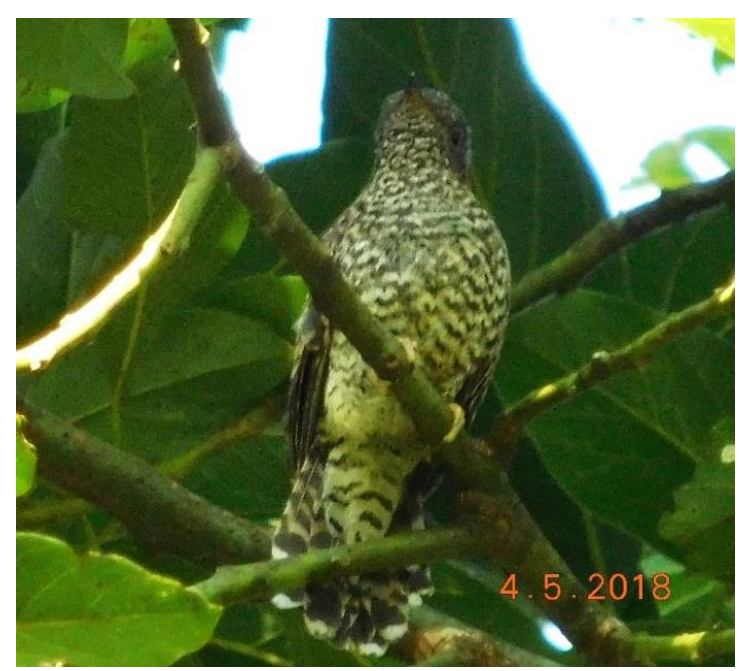

Figure 3. A young cuckoo at Mount Merapi forest, Central Java, Indonesia 


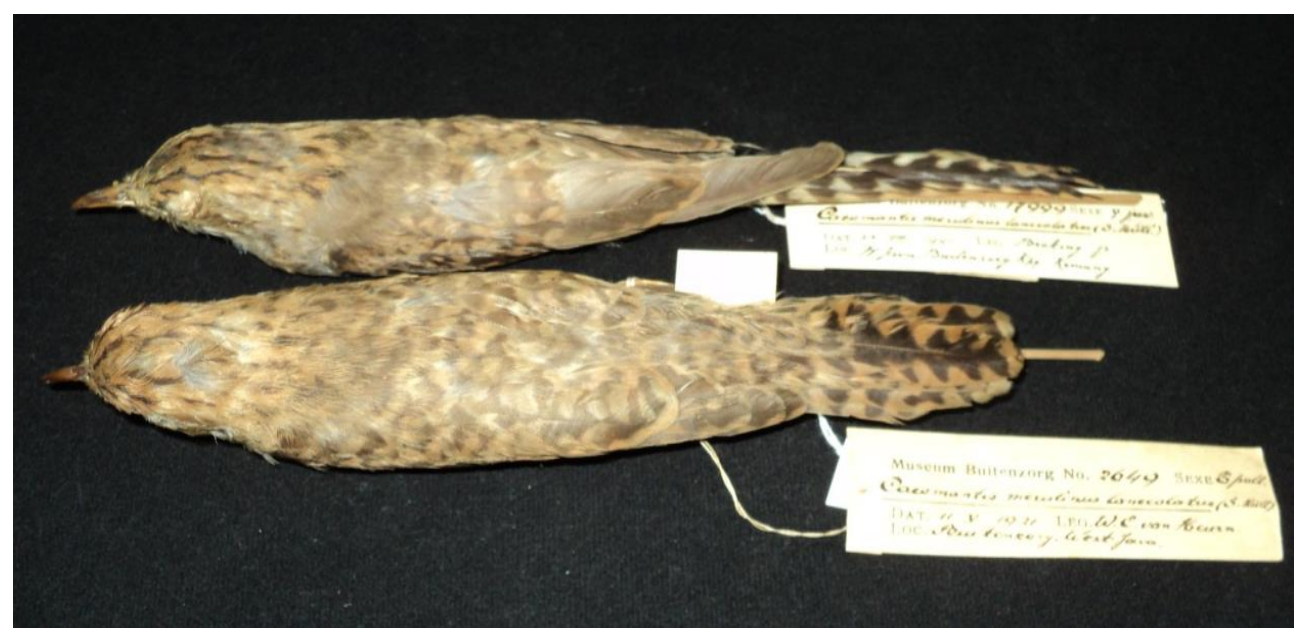

Figure 4. Specimens of juvenile of Plaintive Cuckoo Cacomantis merulinus at MZB, LIPI, Cibinong, Bogor, Indonesia

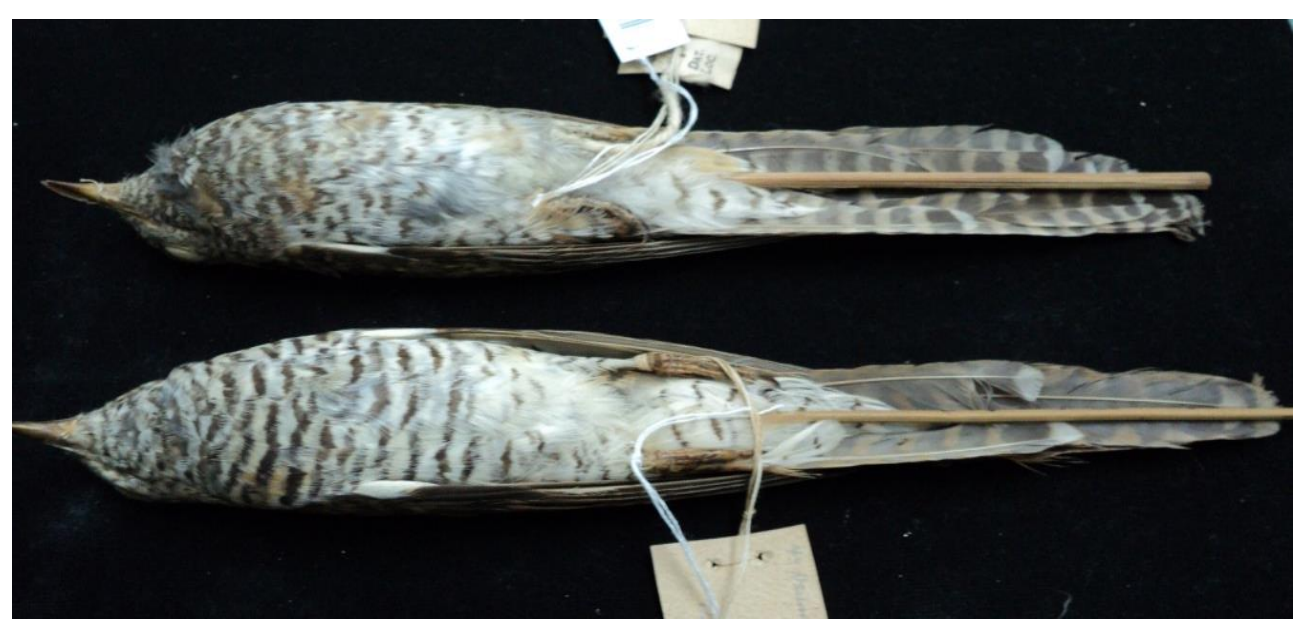

Figure 5. Specimens of juvenile of Rusty-breasted Cuckoo Cacomantis sepulcralis at MZB, LIPI, Cibinong, Bogor, Indonesia

According to our study at Mount Pancar, West Java, we suggest that the young Cuckoo is identified as juvenile of Plaintive Cuckoo Cacomantis merulinus. Because this young cuckoo has specification of Plaintive Cuckoo which has no eye-ring and upper feathers are rufous. The Plaintive Cuckoo could be distinguished from the following species by lack of eye-ring (Stange 2001). If we compare to the references of birds specimens at the Museum Zoological Bogorienses at Cibinong, the characteristics of young Cuckoo are not different, relatively (Figure 4). This case was quite different if it was compared with the young Cuckoos from East Java and Centre Java (Figure 2 and 3). They have smoothie whitish feathers and black-stripped in their breast clearly. They have also such an eye-ring but not bright one and yellowish blue legs. Young Cuckoo's characters from east and center Java are similar if we compare them to the specimens Rusty-breasted Cuckoo Cacomantis sepulcralis in the Museum Zoological Bogorienses, at Cibinong (Figure 5). The sound of calling from this young Rusty-breasted Cuckoo is also similar with "xono-canto" song which was produced by van Balen at Telaga Warna, Dieng, Kejajar, Wonosobo, Centre Java (Naturalis Biodiversity Center 2019) and YouTube (Malaysian Pied Fantail feeding a juvenile Rusty-breasted Cuckoo).

The results showed that the young Cuckoos at Mount Pancar $(620 \mathrm{~m})$ and Mount Merapi forests $(1027 \mathrm{~m})$ were given foods by a pair of the Oriental White-Eyes Zosterops palpebrosus. We know that the Plaintive Cuckoo and Rusty-breasted Cuckoo were brood parasites. The breeding season of Plaintive Cuckoo and Rusty-breasted Cuckoo was on April up to July or September, in Java (MacKinnon 1990). The female of Plaintive Cuckoos and Rusty-breasted Cuckoo put eggs in their nest's hosts at that time. Previously, Plaintive Cuckoos often chose the nests of Common Iora, Ashy Prinias, Common tailor birds, Zitting Cisticola (Anon. 2013). Host list of brood parasitic Old World cuckoos was recorded, namely Aegithina 
viridissima, Cisticola juncidis, Prinia criniger, Orthotomus derbianus, Orthotomus ruficeps, Aethopyga siparaja and Arachnothera affinis (Lowther 2015). Rusty-breasted Cuckoo has some hosts, i.e. Muscicapa vulcani, Rhipidura phoenicura, Rhipidura euryura, Megalurus palustris, Culicapa ceylonensis, Enicurus velatus, Saxicola caprata, Lanius bentet or Lanius schach, Cyornis banyumas, Muscicapa indigo (Hoogerwerf 1949a). The literature did not list Zosterops palpebrosus as host of Plaintive Cuckoo or Rusty-breasted Cuckoo in Java (Hoogerwerf 1949a; Hoogerwerf 1949b, Hoogerwerf 1949c). In Singapura, host of Cacomantis sepulcralis is Malayan Pied Fantail Rhipidura javanica (Grim 2008) and in Malaysia, Cacomantis sepulcralis used Tickell's Blue Flycatcher Cyornis tickelliae as host (BESG 2008).

There aren't many discusses that Oriental White-Eyes was also the host of the Plaintive Cuckoo and Rustybreasted Cuckoo. If we try to compare the eggs of Cacomantis merulinus and Zosterops palpebrosus, there will be a few differences. Primary, the egg color of the Plaintive Cuckoo Cacomantis merulinus lanceolatus entirely turned to white by attenuating ashes, and there are brown spots especially in the tip of the blunt egg. While the eggs color of the Oriental White-Eyes Zosterops palpebrosus is clean white without spots. Meanwhile, Rusty-breasted Cuckoo's egg is brighter white with spots red. However, the Cuckoo's eggs are similar shape. Their eggs shape are oval, with the eggs' shape range index is 74.0 - 75.0\% (Widodo and Widiyaningrum 2018). According to the color and shape of those eggs, there is a possibility that Plaintive Cuckoo and Rusty-breasted Cuckoo use the Oriental White-Eyes as host. Yang et al (2015) stated that host (Tailorbirds) ejected all eggs that differed from the eggs of its own morph but accepted almost all eggs belonging to their corresponding morph. Another case, such as cuckoos (Cacomantis merulinus and Cacomantis sepulcralis) which use multiple host species to raise their chicks, evolve different genes, each one specific to its host species (Anon. 2008). Several studies also indicate that many birds prefer abandoned nest instead of making new nests (Sharma and Sharma 2013).

Whereas, in reality, the cuckoos, i.e. Plaintive Cuckoo and Rusty-breasted Cuckoo, also exploit some songbirds, like Long-tailed Shrike Lanius schach (Figure 2) and Oriental White-eyes Zosterops palpebrosus which have economic potential as the host. However, this opinion needs further research. Previously, the Plaintive Cuckoo usually uses the host of a group of Sylviidae, like Prinia familiaris, Orthotomus sutorius, Orthotomus sepium, and Cisticola juncidis. These might possibly happen. These matters are caused recently by fragmentation of forest as their habitats, also displacement of the function of land and exploiting economical abundant of Sylviidae birds. So that, difficult to interest progressively look for the opportunity newly exploit the other species as their host. Nevertheless, that matter may be not easy for Plaintive Cuckoo and Rusty-breasted Cuckoo.

From the result, we think that our notes have given new interesting information. All birds were not an exception that even small songbirds such as Zosterops groups had a potential for hosting Cuculidae family. The research, however, needs to be continued. Among other things, the research is started with the presence of the Oriental Whiteeyes' nest and the strategy of Plaintive Cuckoo and Rustybreasted Cuckoo to place its egg into the nest of Oriental White-eyes. This research implicates to remind the management authority to maintain the population of remaining songbirds either in conservation areas or in nonconservation areas, as well as their buffer zones.

\section{ACKNOWLEDGEMENTS}

We would like to thank the head of the Research Center for Biology, Indonesian Institute of Sciences, Bogor, Indonesia. We also thank all people, especially, our local guides, namely Udin at Mount Pancar, Untung at Mount Wilis and Daryono from Turgo Hill (Mount Merapi) who have given full help in the fields.

\section{REFERENCES}

Anon. 2019. Plaintive Cuckoo Cacomantis merulinus. www.oeiseauxbirds.com/card-plaintive-cuckoo.html. Available online 1 June 2019. $\begin{array}{lll}\text { Anon. } & 2008 . & \text { Cuckoo. }\end{array}$ https://www.newworldencyclopedia.org/entry/Cuckoo. Available online 1 June 2019.

Avian Report. 2018. Brood Parasitism in Birds. https://www.avianreport.com/brood-parasitism/..Available online 25 April 2019.

Beehler BM, Pratt TK, Zimmerman DA. 1986. Birds of New Guinea. Princeton University Press, New Jersey.

BESG 2008. Pied Fantail feeding juvenile cuckoo. https://besgroup.org>2008/10/13/pied-fantail-feeding-juvenilecuckoo. [31 May 2019].

Buechley ER. 2015. Why shade-grown coffee is good for birds and farmers. theconservation.com/why-shade-grown-coffee-is-good-forbirds-and-farmers-37567.

Coates BJ, Bishop KD. 2000. A Guide to the birds of Wallacea: Sulawesi, The Moluccas and Lesser Sunda Islands, Indonesia. Dove Publications Pty. Ltd., New York.

Grim T. 2008. Begging Behavior of Fledgling Rusty-breasted Cuckoo (Cacomantis sepulcralis). Wilson J Ornithol 120 (4): 887-890.

Hoogerwerf A. 1949a. Een Bijdrage Tot De Oologie van Het Eiland Java. Uitgave van De Kon. Plantentuin van Indonesië, Buitenzorg, Java.

Hoogerwerf A. 1949b. De Avifauna van Tjibodas En Omgeving (Java). Uitgave van De Kon. Plantentuin van Indonesië, Buitenzorg, Java.

Hoogerwerf A. 1949c. De Avifauna van de Plantentuin te Buitenzorg (Java). Uitgave van De Kon. Plantentuin van Indonesië, Buitenzorg, Java.

Iskandar J, Iskandar BS. 2015. Benefit of various birds in the song-bird contest and its impact on bird conservation in nature: A case study in Bandung, West Java. Pros Sem Masy Biodiv Indon 1 (4): 747-752. DOI: $10.13057 / \mathrm{psnmbi} / \mathrm{m010411.} \mathrm{[Indonesian]}$

Krüger O. 2011. Brood parasitism selects for no defense in a cuckoo host. Proc Biol Sci 278 (1719): 2777-2783. DOI: 10.1098/rspb.2010.2629.

Lowther PE. 2015. Host List of Avian Brood Parasites_2_Cuculiformes Old World Cuckoos. https://www.fieldmuseum.org/sites/default/files/plowther/2015/06/02/ owcuckoo-jun2015.pdf.

MacKinnon J. 1990. A Field Guide to the Birds of Java and Bali. Gadjah Mada University Press, Yogyakarta. [Indonesian]

MacKinnon J, Phillipps K, van Balen B. 1998. A Field Guide to the Birds of Sumatra, Java, Bali and Borneo (Include Sabah, Sarawak and Brunei Darussalam). BirdLife International Indonesia Programme R\&D for Biology Indonesian Institute of Sciences, Bogor [Indonesian] 
Naturalis Biodiversity Center 2019. Telaga Warna, Dieng, Kejajar, Wonosobo, Jawa Tengah. https://www.xenocanto.org/location/map?lat=-7.2131\&long $=109.9142$.

Sharma M, Sharma RK. 2013. Breeding biology of red-vented bulbul (Pycnonotus cafer). Intl J Zool Res 3 (5): 1-4.

Stange M. 2001. A Photographic Guide to the Birds of Indonesia. Periplus Editions (Hongkong) Ltd., Hong Kong.

Tejeda-Cruz C, Sutherland WJ. 2004. Bird response to shade coffee production. Anim Conserv (7): 169-179. DOI: 10.1017/S1367943004001258

Tjakraningrat KPH. 1965. Betaljemur Adammakna. Somodidjojo Mahadewa, Yogyakarta. [Indonesian]

Widodo W. 2013. Study on species diversity of birds in three land use types at the Gunung Pancar Tourism Park, Bogor. Proceeding of the 10th National Seminar on Biology, Science, Environment and Learning. Sebelas Maret Surakarta University, Surakarta. July 6, 2013 [Indonesian]
Widodo W. 2015. Qualitative assessment of bird species abundance in the Telaga Bodas Mountain Forest, Garut, West Java. Biosaintifika J Biology and Biology Education 7 (1): 37-47. DOI: 10.15294/biosaintifika.v7il.3533. [Indonesian]

Widodo W. 2016. Relative Abundance, Distribution and Natural Food Resources of Restricted-range Birds Species. In: Hayati A. (ed). Proceeding of the 6th Biodiversity National Seminar on Airlangga University, Surabaya. September 3, 2016. p.601-615. [Indonesian]

Widodo W, Widiyaningrum P. 2018. Selection of Cuculidae to Hosts Based on the External Characteristics of the Eggs. Biosaintifika J Biology and Biology Education 10 (1): 1-8. DOI: 10.15294/biosaintifika.v10il.9939.

Yang C, Liang W, Antonov A, Cai Y, Stokke BG, Fossøy F, Moksnes A, Røskaft E. 2012. Diversity of parasitic cuckoos and their hosts in China. Chinese Birds 3 (1): 9-32. DOI: 10.5122/cbirds.2012.0004.

Yang C, Huang Q, Wang L, Aiwu, J. 2015. Plaintive cuckoos do not select tailorbird hosts that match the phenotypes of their own eggs. Behavior Ecol 27 (3): 1-7. DOI: 10.1093/beheco/arv226. 